\title{
Community Satisfaction in the Design, Implementation and Motivation of the Company Community on Batik Alam Malon Indonesia Power CSR Project
}

\author{
Agus Naryoso \\ \{agusnaryoso@lecturer.undip.ac.id\} \\ Universitas Diponegoro, Indonesia
}

\begin{abstract}
PT. Indonesia Power PGU Semarang is a company that provides national electricity energy needs. The Company as a State-Owned Enterprise (SOE) is obliged to carry out activities intended as a form of commitment to the environment. The activities are packaged in the form of community development and corporate social responsibility. The activity is carried out as a form of compliance as a state-owned enterprise on the advice of the government, in addition also as a way to establish good relations with the community and secure the company's business operations, benefit obtained by Indonesia Power from the implementation of these activities is mainly in the relationships and good relations of various parties involved in csr activities. The ease of access to licensing from various parties is also felt. Although this is not in material form, but these are three things that cannot be easily obtained if the company does not have the faith or desire to build good relationships with the relevant stakeholders. This study aims to determine the level of stakeholder satisfaction in the motivation, planning and implementation of PT. Indonesia Power Semarang PGU.
\end{abstract}

Keywords: Stakeholder, Batik Alam, Corporate Social Responsibility

\section{Introduction}

Corporate social responsibility is a form and contribution of the company to the sustainability of the life of the surrounding community, the activity to show commitment to social, economic and environmental issues of the community. Corporate Social Responsibility activities are expected to answer and meet the needs of the community and have many positive impacts on the company, namely being able to maintain or boost reputation in order to gain high public trust and be able to build a strong corporate brand identity, companies that have awareness of carrying out CSR activities well should get broad opportunities and strong support to continue to carry out their business operations well, the commitment and support will come from various community stakeholders, local governments and shareholders. The regulator will give recognition of the credibility of the business institution because it is law-abiding and ethical good business, so corporate social response activities are important for the sustainability of a company in the public interest. CSR in the long term will provide a profitable business guarantee, not only increase public trust, strengthen investment, but the implementation of CSR activities will certainly secure the company's business operations so that the company can run operations without the constraints that arise from the nearest context. Law no. 40 of 2007. Article 74 paragraph reads thus: (The Company that conducts its business activities in the field 
or related to Natural Resources must carry out Social Responsibility with the Environment). Wuryani and Wahyu [1] stated that empowerment is a form of social change towards a better and more prosperous society. The above concept is in line with the company's policy to prioritize non-consumptive assistance, but more on efforts to encourage economic independence of Gunungpati sub-district people in order to overcome their own economic problems. A wellmanaged CSR will have a big impact on business development. the success of the company depends heavily on the company's relationship with stakeholders and the level of stakeholder satisfaction in the company, it shows that either the company or the government should start to be critical and Aware to carry out CSR activities, where the Company's CSR will influence consumer decisions. Consumers are more likely to give greater choice to companies engaged in social and environmental activities, support and appreciate by purchasing products of companies that do CSR, therefore the most effective CSR activities are csr activities that are able to improve the consumer's attitude towards the company, increase consumer loyalty, reduce the level of skepticism that is concern and reduce consumers and doubts about the company's products and services. Second, CSR will help companies minimize the risk of any crisis. Tsoutsoura [2] recommends three types of risks related to CSR, corporate governance, environmental and social aspects. Companies that adopt more transparent CSR principles will have less risk of bribery and corruption. They will also implement strict quality and environmental controls. In line with the above, and in order to get the main essence of CSR implementation every company is required to have good communication quality in communicating and building relationships with its stakeholders, especially beneficiaries. Communication quality is a reciprocal process between the source of the message or the information and the recipient of the message. When someone relays a message to another person and the person responds, then the communication process is said to take place effectively. CSR activities carried out by many companies are often carried out without good planning, whereas planning activities are necessary to map and know the needs and desires of the beneficiaries.

Analysis of achievements is also very important, many companies make a lot of money but the sustainability is not the way, there is no mentoring that intensively communicates with the beneficiaries. It is important to build the strength of the business reputation, through intensive publicity in the mass media of print, electronics and online, the mission of the purpose and desire of the company can be conveyed well. In addition, the most important thing is that the news will be able to form positive attitudes and opinions. Efforts to gain great publicity need to be made using the right media relations strategy, where PR is required not only to rely on the power of money to pay for news. Unfortunately, many implementers of this activity do not understand the value of strategy, the focus is only on carrying out CSR activities once it is completed, even though the news has a big effect in fostering sympathy and public trust. The news will be an alternative means of providing reporting to the government about the activities carried out, whether the activity is able to provide impact and great benefits for the development and development of the local economy.

This study uses a paradigm of constructivism as defined in this paradigm. See CSR as the company's commitment to minimize or eliminate short-term harmful effects and maximize longterm profits that have a positive impact on the CSR activities community can be referred to as business responsibility. CSR is conceptualized as a sense of social responsibility that has fundamental benefits on the company, society and the environment. In this context the company uses CSR conception not only to build good relationships with the government, but also with all relevant stakeholders in order to ensure sustainable business performance.

CSR can be defined as a paradigm to address the dangers of the company. Garriga and Mele [3] conducted a four-dimensional mapping of CSR that included instrumental, political, 
integrative, and ethical theory, the four dimensions of CSR explained that CSR is part of the business obligation to pursue profit, awareness of performing social obligations, instilling values and ethics in the development of its business. Public confidence in the products and services offered by the company. The purpose of Media Relations Steps taken when determining the function of media relations, is certainly expected to be in accordance with the goals that will be achieved by public relations. The goal as the purpose of the attitude or action taken without giving birth to a new problem of the decision taken. Carrying out the PR function by using media relations as a strategy is the right decision because the company's back and forth relies heavily on harmonization of the relationship between the press and the company. Appropriate means for the benefit of the widest possible publication of the activities and policies taken by companies that are considered good for the public to know.

The purpose of the relationship with the media is to foster trust so that it can produce a good relationship continuously between the company and the press. Related to reporting, a new reporting model emerged and was developed by The International Integrated Reporting Council's with the support of the Global Reporting Initiatives. Integrated Reporting has principles and elements in accordance with the presentation framework published by IIRC. In addition, the company also hopes that the reporting can also give a good impression so that the positive image of the company can be formed.

The hidden message and expectations want to be conveyed by the company to stakeholders as input and the basis of their consideration in carrying out a decision-making action. One important theory that is often used or contributes to CSR development is stakeholder theory. The reputation of the corporation as described by Fombrun [4] is based on a collective assessment containing views and beliefs about the company's ability and willingness to meet the interests of various relevant stakeholders. Bromley and Sandberg see reputation as a shared social impression and consensus on how companies behave in certain situations is a powerful contributing factor to business success. Bennett and Rentschler define reputation as corporate image and identity associated with consideration of value, long-term commitment, consistency, firmness and corporate credibility.

This has implications that PR programs should be designed by emphasizing the goal of building relationships by engaging stakeholders as part of strategies and tactics to achieve targets. The importance of stakeholder engagement shows that between business and stakeholders are in a symbolic relationship and the behavior of both is emphasized in efforts to build the effectiveness of organizational relationships. Ledingham and Bruning [5] emphasize that communicating through CSR programs should be consistent in efforts to maintain good and profitable relationships between organizations and stakeholders.

Research conducted is a type of qualitative research that uses a qualitative descriptive approach using case studies. Primary data is data that researchers collect directly from the main data. Secondary data is data from other people's research results created for different purposes. Secondary data sources come from archival documents, previous research results and other sources that have relevance to the problems being examined that serve as complements to the data.

According to Creswell and Poth [6], for case studies as well as ethnographic analysis consists of detailed descriptions of the case and its settings. If a case displays the chronology of an event then analyzing it requires multiple data sources to determine the evidence at each phase in the evolution of the case. Finally, researchers developed naturalistic generalizations through data analysis, these generalizations are taken through people who can learn from a case, whether their own case or apply it to a case population. Creswell and Poth [6] further added a description of the case as a detailed view of the case. In the final part of this study, we can develop 
generalizations about the case viewed from various aspects, in comparison, distinguished by other literature.

\section{Result and Discussion}

Many private companies or state-owned enterprises (SOEs) develop so-called Corporate Social Responsibility or better known as CSR. Many researchers, observers found that there is a positive relationship between corporate social responsibility (CSR) and financial performance, despite its long-term impact. CSR implementation is also not considered a cost anymore, but rather a corporate investment. One of them in one of the SOEs is PT Indonesia Power Semarang PGU.

The most ideal CSR activities are CSR activities that are oriented towards the needs and efforts to solve the problems of the target, especially those who live in the area or who live close to the company. The scope of Indonesia Power's CSR implementation includes Economics (selfsustaining community economic improvement program through SME development), Education (education and skills program in improving community capabilities through skills and profession education in communities, schools, and universities), Environment (environmental innovation program in supporting clean and green generation, through the collaboration of companies, communities and other institutions such as scouts and KLHK), Health (enterprise innovation program in improving integrated public health with education, environment, and economy), Women Empowerment (skills improvement program, maternal and child health and business development for women).

In the Economic sector empowers Kampung Batik Alam Malon. Indonesia Power also has a Smart IP program that stands for Indonesia Power-Internship, Assessment and Certification Program, cooperation between Indonesia Power and the world of Education in the preparation of skilled personnel in the field of power generation. Meanwhile, from the environmental sector, Indonesia Power has a program as a form of corporate responsibility to the environment such as garbage banks with the manufacture of polders so as not to rob in the surrounding area. As well as health, Indonesia Power also holds free consultations. For Women Empowerment through KUB Fish and Food Processing KUB Prima Indo.

Indonesia Power's CSR activities are already mapping, then there are measures of bus scale plan related to the potential of each area or village in mapping. Starting from the beginning invite the group before becoming a partner, the group that is in the ring 1 environment, PMK then village device, and prospective accompanying activities. After being invited to connect multi forum activities, see the program already running and bring a new kind of innovation into the program. Examples of garbage banks have been run and collaborated with food stalls, then from garbage banks the result can be for elderly Posyandu.

In carrying out its program, Indonesia Power invites the public, business development and government. On the allocation of $100 \%$ funding to empowerment and there are three programs implemented. Community communication, community service and community empowerment. Community empowerment is allocated the highest funds between $60-65 \%$ then the rest is divided between community service and community communication. Community services such as scholarships, mobile medicine and then Posyandu, infrastructure assistance in schools. The beneficiaries are already mapping there is data from third parties, namely conducting surveys, from the village there is rill data in the field. At the end of 2019 want to implement a childfriendly village program. In the area around Indonesia Power has many citizen forums and provides funding assistance to the forum. The forum is a citizen forum, a forum in partnership 
with the police and the community as well. For the theist percentage of community empowerment is $60-65 \%$, then public relations $15 \%$ and the remaining $25 \%$ community service. The activities carried out by the company are one of the indicators of the success of proper gold. In environment Indonesia Power itself becomes a measure or indicator Indonesia Power Semarang has CSR activities, the assessment indicator is proper green. The term proper green cluster assessment is also a reference, example yesterday green in the third rank of its value. By the community of 60, last year, this year it remained green but there was a CSR rating of 80 .

In social mapping it tries to make identification that if there is potential what is related to natural resources as well as other potentials. For example, Lorok Pond, Tanjung Mas there are farm farmers (some people manage ponds). Once complained of hot water. In this case immediately followed up with then discussed the initial procedure to the village is indeed what the problem is, from our side invite directly academics (Unnes).

Many companies do CSR-related activities that are oriented to social or improve the welfare activities of the surrounding community. In the program is certainly orientation if providing capital assistance or funding assistance in the form of tools for the community the orientation goal is to improve the welfare of the community, to ensure that what they want is really a real problem. So, what indicators will be used complete, such as demographic factors such as income level, employment, education, number of families covered then social facilities, environmental support facilities.

CSR activities that are felt directly by Indonesia Power starting from that basis are felt once. Then at times such as pandemic conditions like this, coordinating to the service, police and others is relatively smooth and assisted. There are two things that are first good Community Relations then the second is good Government Relations. In internal info activities the requirement must use $20 \%$ of local people. In the view of the justice community, it's what it's like, whether it's directly getting more rations or ring 1 all of them and that there's been protests and it can be muted because the event goes well, what's also good from the village, people from the police force who have often had activities are also helped. But the info is faster, so if in a place such as security environment team's observation activities in Gojek using the apparatus, but the information in can be much faster than using such apparatus. And helped by that, he said his people's planning could be better.

Aspects of the timeline, reporting is not just reporting activities or reporting activity information carried out through official lines or formal lines such as providing reports to the central government, providing reports to Indonesia Power at the head office (official line). While reporting more information to events, the example of the morning makes informal reporting, for formal reports obtained monthly.

One of the partners of Batik Alam Malon for example electric batik has patented batik electric motif. The type or type of design created by Alam Malon yet. Like coloring though cannot be strengthened with patents but the beginnings of the construction partners give a lot of training out so one of the points as well and maybe in this year try to find one example of red coloring does not yet exist.

Improving living standards there must be more fresh money assistance to the example to scholarships, if others more to community empowerment, education related to community empowerment programs. If farmers pond how to manage the pond, also from food managers also training towards increasing their production. From the quantitative survey of CSR programs emphasized towards ISO26000 programs such as IP care was started, initially in 2002, and felt more in 2014 conducting evaluation and strategic planner program 5 years.

The award has been obtained from CSR activities conducted by Indonesia Power Semarang in 2018 one of the partners who received the MSME award. The company's partners 
are awarded and usually indirectly the culture of the target partner will be given appreciation obtained due to the assistance of the activity.

In addition, Indonesia Power's CSR activities in fostering an anti-corruption culture have been implemented internally, such as socializing to its employees that Indonesia Power has GCG, then Indonesia Power has also prepared advice boxes and inputs to its partners and stakeholders and even employees related to the abuse of authority, bribery, and others. All its activities are already using the application, so that the data can be monitored directly. For example, online payments can be viewed, and even partners can see how far the process is going. Indonesia Power also carries out CSR activities related to thematic human rights. As with any term of the Collective Labor Agreement (PKB), which is the place to arrange maternity leave, the rights of women workers, the provision of lactation space that is not time-limiting, and sustainable at a later career level. All of these regulations are set out in the Board of Directors' Decree. In the work unit there is also a so-called Employees Association, which is a container to accommodate input, suggestions, protest actions, and other things that if it becomes unrest employees can be voiced to the management of Indonesia Power.

The benefits obtained by Indonesia Power from the implementation of these activities are mainly in the relationships and good relations of various parties involved in these CSR activities. The ease of access to licensing from various parties is also felt. Although these are not in material form but these are three things that cannot be easily obtained basically.

In a company or an institution, CSR activities are important to implement. Whether it's for a relationship, a good relationship, support, and cooperation or partnership. CSR is a corporate social responsibility that basically has concepts and objectives in accordance with the mission vision and is continuing. The concept developed is also adapted to the dimensions that the company wants to apply. The implementation of CSR on growing issues is also something to anticipate. David and Foray [7], McElroy [8], Sneider et al. [9], Nwanji and Howell [10], Husted and Allen [11], Turker [12], Vilanova et al. [13], Melo and Garrido-Morgado [14], Kumar [15] by addressing society's needs and demands through the inclusion of CSR-related. activities, firms are able to provide better products and services. The facts above show that the needs of CSR assistance recipients have a very important role in the success of CSR activities. The fulfilled needs of beneficiaries will build good relations between the company and stakeholders and reduce the risk of conflict, and increase long-term business profits.

\section{Conclusion}

Basically, every CSR activity needs to be mapping or social mapping. Where the mapping is done so that the activity is clear, targeted, and in accordance with the needs and desires of the market or target. This is done so that the activity is not as good and not original in the expenditure of the cost of its activities. PT Indonesia Power Semarang PGU develops their CSR activities together with several stakeholders and their partners. Their orientation is to meet the needs and solve the problems of their targets and scope. IP Pintar in the field of education, Batik Alam Malon in the economic sector, free consultation in the field of health, women's empowerment on human rights, and many other CSR activities of Indonesia Power. All its activities are sustainable. 


\section{References}

[1] E. Wuryani and W. Purwiyastuti, "Menumbuhkan Peran Serta Masyarakat dalam Melestarikan Kebudayaan dan Benda Cagar Budaya melalui Pemberdayaan Masyarakat di Kawasan Wisata Dusun Ceto," Satya Widya, vol. 28, no. 2, pp. 147-154, 2012.

[2] M. Tsoutsoura, "Corporate social responsibility and financial performance," 2004.

[3] E. Garriga and D. Melé, "Corporate social responsibility theories: Mapping the territory," J. Bus. ethics, vol. 53, no. 1, pp. 51-71, 2004.

[4] C. Fombrun, "Reputation," Wiley Encycl. Manag., pp. 1-3, 2015.

[5] S. D. Bruning and J. A. Ledingham, "Organization-public relationships and consumer satisfaction: The role of relationships in the satisfaction mix," Commun. Res. Reports, vol. 15, no. 2, pp. 198-208, 1998.

[6] J. W. Creswell and C. N. Poth, Qualitative inquiry and research design: Choosing among five approaches. Sage publications, 2016.

[7] P. A. David and D. Foray, "Fundamentos economicos de la sociedad del conocimiento.(Economic Foundations of the Knowledge Society. With English summary.)," Comer. Exter., vol. 52, 2002.

[8] M. W. McElroy, "Social innovation capital," J. Intellect. Cap., 2002.

[9] J. Snider, R. P. Hill, and D. Martin, "Corporate social responsibility in the 21st century: A view from the world's most successful firms," J. Bus. ethics, vol. 48, no. 2, pp. 175-187, 2003.

[10] T. I. Nwanji and K. E. Howell, "A review of the two main competing models of corporate governance: The shareholdership model versus the stakeholdership model," Corp. Ownersh. Control, vol. 5, no. 1, pp. 9-23, 2007.

[11] B. W. Husted and D. B. Allen, "Strategic corporate social responsibility and value creation among large firms: lessons from the Spanish experience," Long Range Plann., vol. 40, no. 6, pp. 594 610, 2007.

[12] D. Turker, "Measuring corporate social responsibility: A scale development study," J. Bus. ethics, vol. 85, no. 4, pp. 411-427, 2009.

[13] M. Vilanova, J. M. Lozano, and D. Arenas, "Exploring the nature of the relationship between CSR and competitiveness," J. Bus. Ethics, vol. 87, no. 1, pp. 57-69, 2009.

[14] T. Melo and A. Garrido-Morgado, "Corporate reputation: A combination of social responsibility and industry," Corp. Soc. Responsib. Environ. Manag., vol. 19, no. 1, pp. 11-31, 2012.

[15] S. Kumar and A. Kidwai, "CSR disclosures and transparency among top Indian companies," Int. J. Indian Cult. Bus. Manag., vol. 16, no. 1, pp. 57-70, 2018. 